\title{
AVALIAÇÃO DOS NÍVEIS SÉRICOS DE CÁLCIO, FÓSFORO E MAGNÉSIO EM VACAS LEITEIRAS COM HIPOCALCEMIA
}

(Evaluation of serum levels of calcium, phosphorus and magnesium in dairy cows with hypocalcemia)

Felipe Eduardo Dal Más, Gustavo Luis Dal Más, William Rodrigues, Marilene Machado Silva

Universidade Federal do Paraná, Palotina, Paraná, Brasil.

*Correspondência: dalmasfelipe@gmail.com

RESUMO: A transição do estado de vaca seca para lactante aumenta abrupta e intensamente a demanda de nutrientes para produção de leite. O cálcio tem alta concentração no colostro e leite, e a falha na adaptação a esta demanda, leva à hipocalcemia, manifestando-se pela incapacidade da vaca se manter em estação. A redução dos níveis séricos de fósforo e magnésio também podem levar o animal ao decúbito (GOFF, 2015), assim avaliar estes minerais é essencial nestas vacas em decúbito, sendo o objetivo deste trabalho avaliar as concentrações de cálcio, fósforo e magnésio em vacas com hipocalcemia clínica. Foram avaliadas 15 vacas com hipocalcemia, em decúbito persistente até $48 \mathrm{~h}$ pós-parto, com reposta ao tratamento com cálcio intravenoso. 0 grupo controle foi constituído por 20 vacas sadias com até 30 dias pós-parto. Antes do tratamento foi coletado sangue, com o soro obtido foram mensuradas as concentrações de cálcio, fósforo e magnésio, em analisador bioquímico automático BS120 Mindray, no Laboratório Clínico Veterinário UFPR-Setor Palotina. Os grupos foram comparados por teste Teste $t$ não pareado $(p<0,05)$, e comparados com intervalos de referência para cálcio $(8-10,5 \mathrm{mg} / \mathrm{dL})$, fósforo $(4-6 \mathrm{mg} / \mathrm{dL})$ e magnésio (2-2,3mg/dL) (GOFF, 2015). Todos os animais controle estavam dentro ou acima destas concentrações de minerais. A média $(\mathrm{mg} / \mathrm{dL})$ e desvio padrão de cálcio para as vacas hipocalcêmicas foi $3,6 \pm 0,9$, fósforo $3,4 \pm 1,5$ e magnésio $2,56 \pm 0,62$, para o grupo controle cálcio $9,2 \pm 1,1$, fósforo $8 \pm 2$ e magnésio $2,58 \pm 0,32$, apresentando diferença para cálcio $(p=<0,0001)$ e fósforo $(p=<0,0001)$, e magnésio não apresentou diferença $(p=0,95)$. Comparado às referências, todas as vacas apresentaram hipocalcemia, com valores de cálcio de 2,7 a 5,4mg/dL. O limiar mínimo de cálcio para que os animais se mantenham em estação é controverso, havendo a citação de $5 \mathrm{mg} / \mathrm{dL}$ (GOFF, 2015), no presente estudo foi 5,5mg/dL. Além disso 66,7\% tinham hipofosfatemia e $20 \%$ hipomagnesemia. Pontos críticos de fósforo $(1,5 \mathrm{mg} / \mathrm{dL})$ e magnésio $(1,2 \mathrm{mg} / \mathrm{dL})$ para causar decúbito (GOFF, 2015), foram atingidos em duas vacas para fósforo, mas estas tinham hipocalcemia grave, abaixo de 3,2mg/dL. A manutenção dos níveis sanguíneos destes minerais depende do consumo, e para cálcio e fósforo também da reabsorção óssea (GOFF, 2006), estimulada pelo paratormônio, todavia a hipomagnesemia reduz a ação deste hormônio (GOFF, 2015) assim, a hipomagnesemia apresentada por algumas vacas pode ter contribuído para o desenvolvimento de hipocalcemia. Fatores como composição da dieta, concentração de magnésio e outros minerais, e CMS, determinam a absorção de magnésio (GOFF, 2006), explicando a variabilidade entre animais, apresentando ou não hipomagnesemia, e assim, não houve diferença para este mineral. O fósforo foi menor para vacas hipocalcêmicas, sendo a hipofosfatemia muito presente, demonstrando a relação com o cálcio, provavelmente pelas concentrações de fósforo no leite, sua dependência da absorção da dieta e reabsorção óssea, como ocorre para o cálcio. Assim, a hipocalcemia nas vacas leiteiras está associada à redução de outros minerais como fósforo e magnésio, que podem contribuir para o desenvolvimento do quadro, embora provavelmente não determinantes do decúbito, e a avaliação dos três minerais é recomendada, contribuindo para diagnóstico e ajuste da dose destes íons no tratamento.

Palavras-chave: doenças metabólicas; hipofosfatemia; hipomagnesemia; minerais.

Nota: Projeto aprovado por comitê de Ética, protocolo n¹5/2019, 02/05/2019, CEUA UFPR Palotina. 


\section{Referências}

GOFF, J. P. Calcium, Magnesium, and Phosphorus. In: SMITH, B. P. Large Animal Internal Medicine. 5. ed. St. Louis: Elsevier, 2015. p. 1258-1266.

GOFF, J. P. Macromineral physiology and application to the feeding of the dairy Cow for prevention of milk fever and other periparturient mineral disorders. Animal Feed Science and Technology. v. 126, p. 237-257, 2006. 